\title{
Assessment of biochemical compositions and mineral contents of carapace of some important commercially crustaceans and mollusks organisms from Egyptian and Saudi Arabia coasts as a new animal feed
}

\author{
Hala Ali Abdel-Salam \\ Department of Zoology, Faculty of Science, Cairo University, Egypt
}

Email address:

Hala.ali2010@yahoo.com

\section{To cite this article:}

Hala Ali Abdel-Salam. Assessment of Biochemical Compositions and Mineral Contents of Carapace of Some Important Commercially Crustaceans and Mollusks Organisms from Egyptian and Saudi Arabia Coasts as a New Animal Feed. American Journal of BioScience. Vol. 1, No. 2, 2013, pp. 35-43. doi: 10.11648/j.ajbio.20130102.12

\begin{abstract}
Carapace of commercial crustaceans species (mantis shrimps ; Erugosquilla. massavensis, the penaeid shrimps ; Peaneus. semisulcatus ; Metapenaeus monoceros and blue crab; Portunus pelagicus ) and commercial mollusks (cuttlefish ; Sepia and bivalve mollusks; Cardium edule) were chosen for this study to assess carbohydrates, protein, lipids and to estimate their $\mathrm{Fe}, \mathrm{Cu}, \mathrm{Co}, \mathrm{Hg}, \mathrm{Pb}$ and $\mathrm{Cd}$ contents, as an attempt to use the carapace of marine invertebrates organisms as a cheap protein animal feed. Additionally, to investigate the interrelation between the exoskeleton of these marine animals and water pollution. In the terms of nutritive quality, the present results show that the carapace of both sex of E. massavensis was the richest nutritive source compared to that of all studied samples. Furthermore, the recorded data indicate that the exoskeleton of all studied crustaceans organisms and the internal shell of cephalopod mollusks had higher nutritive contents than the exoskeleton of bivalve mollusks. Concerning with heavy metal bioaccumulation, the present study show that the carapace in both sexes of E. massavensis accumulated higher percentages of the determined metals than those of other studied crustaceans species. On the other hand, Sepia spp. exhibited the lowest levels of the studied metals comparable to crustaceans and $C$. edule species. While, all species of $C$. edule accumulated the higher concentrations of Fe, $\mathrm{Co}, \mathrm{Pb}$ and $\mathrm{Cd}$ in their shells than those in all studied crustaceans species. In this respect, the values of Metal Pollution Index (MPI) of studied essential elements in all studied species were higher than that of non- essential elements. Moreover, the highest values of essential and non-essential elements were recorded in all E. massavensis and C. edule samples respectively. While, the lowest level was detected in Sepia spp. followed by crab species. This primary work is an attempt to pursue further research in this line and will also be useful in the preparation of value added sea foods; the findings of the current study may help to select the appropriate species for animal feed. Moreover, the present study suggests that the exoskeleton of crustaceans and bivalves mollusks can be used as indicator of water pollution and this suggest their tendency to detoxification mechanism of heavy metals as a mean of protection. This in turn suggests that a close monitoring program is need to ensure the safety of these crustacean and mollusks species as a food source for animals.
\end{abstract}

Keywords: Crustaceans, Carapace. Chemical Composition, Nutritive Value-Animal Feed- Heavy Metals Accumulation, Mollusks

\section{Introduction}

Crustaceans and mollusks are different creatures, but they do have something in common, a shell. Crustaceans, such as crabs, lobster and shrimp have an exoskeletons as opposed to a true shell. The exoskeleton is comprised of protein, chitin and calcium carbonate. It is made of separate plates which are connected by a thin membrane; this creates joints allowing the crustacean to move. Mollusks, such as snails, clams and oysters, have a prominent, hard exterior shell, traditionally known as seashells. Not all mollusks have an external shells, such is the case of squid, octopus and cuttlefish which have an internal shell. Like the crustacean's exoskeleton, the mollusk's shell serves to protect the soft-bodied animal against predators[1]. Recently, there is a growing concern of the value of 
biochemical estimations of exoskeleton of marine organisms for determining the possibility of using it as an alternative source of food for animals [2]. Since, the major product of the marine food industry is edible muscles which constitute only about $50 \%$ to the marine organism wet body weight as in shrimps. The other half, the residual biomaterial (exoskeleton) which contains many valuable compounds can be valorized further by fractionation into its major components: protein, minerals and chitin. The protein has high potential as a human food additive and food supplement while the chitin is usually converted into its deacetylated product, chitosan that in particular, has many applications in foods, medicines ,cosmetics and water purification. Various other valuable products can be extracted from the biomaterial. These include shrimp flavor components [3]. Therefore, the aim of the present study is to evaluate the biochemical components of carapace of some important commercially crustaceans and mollusks species collected from the Egyptian coasts and Saudi Arabia coasts as a cheap, safe and new nutritive source for animals.

In this work, marine invertebrates species were selected on the basis of their economic importance, abundance and use pattern in the study areas. The mantis shrimps $E$. massavensis which is a potentially an edible crustaceans that has growing economic importance in the area of the Suez Canal and in the Mediterranean Sea, the nature of its fishery is therefore, described as apart of the overall fishery of commercial crustaceans [4-6]. Additionally, E. massavensis is now important components of local aquatic fauna in Egypt that have a small yet growing importance in our markets [6]. Moreover, P. semisulcatus and $M$. monoceros are the main commercially exploited penaeid shrimps. As well as, the blue crab $P$. pelagicus, Sepia and $C$. edule are the most popular and highly exploited crustacean and mollusks species in Saudi Arabia.

Over the last few decades the marine environment has been contaminated by persistent pollutants of agriculture and industrial origin. Heavy metal contamination has been identified as a concern in coastal environment, due to discharges from industrial wastes, agricultural and urban sewage. The levels of heavy metal are known to increase drastically in marine environment through mainly anthropogenic activities. Despite the low concentrations of heavy metals in the surrounding medium, aquatic organisms take them up and accumulate them in their tissues through a variety of pathways, including respiration, adsorption and ingestion to concentrations several folds higher than those of ambient levels [7]. So, marine organisms are considered as good indicators for the long term monitoring of metal accumulation in the marine environment [5]. A major hazard which may be associated with the use of dietary feed ingredients is the presence of potentially toxic mineral elements such as the accumulative elements copper, lead, cadmium and mercury [8]. Therefore, to ensure the safety of the selected marine organisms in this study for animal consumption, the accumulative capacity of these marine organisms with the heavy metal concentrations should be estimated in their shells.

Minerals are particularly significant in the different biological functions. Such as $\mathrm{Cu}$ and $\mathrm{Fe}$ are oligoelements which play vital roles in the enzymatic and respiratory processes of marine organisms[9, 10]. However, $\mathrm{Cu}$ is the most toxic metal after mercury and silver [11] and considered as public health hazard if abnormal high level of $\mathrm{Cu}$ ingested. Furthermore, $\mathrm{Co}$ is readily absorbed from the gastro-intestinal tract and the surrounding water by fish and crustacean and other aquatic organisms. It is an essential trace mineral that is a constituent of vitamin $\mathrm{B}_{12}$. The main function is to prevent anemia. It works with vitamin $B_{12}$ in the production of red blood cells and to ensure the health of the nervous system [12]. On the other hand, the heavy metals $\mathrm{Hg}, \mathrm{Pb}$ and $\mathrm{Cd}$ which are non-essential trace metals and already toxic in very low concentrations. They cause metabolic anomalies due to their competition with the essential metals for binding sites and also their interference with sulfhydryl groups and structural protein [13-15].

So, the purpose of the present work was, therefore, to assess carbohydrates, proteins, lipids contents and the residual heavy metal concentrations $(\mathrm{Cu}, \mathrm{Fe}, \mathrm{Co}, \mathrm{Hg}, \mathrm{Pb}$ and $\mathrm{Cd}$ in exoskeleton of some commercially crustaceans and mollusks species which may in the future play an important role in some pharmaceutical industries and may be used as a specific health animal foods. Furthermore, to investigate the interrelation between the exoskeleton of these marine organisms and water pollution.

\section{Material and Methods}

\subsection{Collection of Samples}

The study was carried out on the marine crustaceans species ( mantis shrimps; shrimps and crabs) and mollusks species (cephalopods and bivalve mussels) that were collected separately from different sites as follows:

A-Both sexes of marine mantis shrimp E. massavensis that were collected from fishing ports of the Suez and Ismailia regions, Egypt

B- Red Sea strain crustaceans included :male and female of $P$. semisulcatus (shrimps); P. pelagicus (crabs); cephalopod mollusks(Sepia spp.) and bivalve mussel mollusks ( $C$. edule) were obtained from local fishermen at Jeddah, Saudi Arabia.

C- Arabian Gulf strain crustaceans : both sexes of $M$. monoceros (shrimps), $P$. pelagicus and (mollusks cephalopods) Sepia spp. and (bivalve mollusks) C. edule were collected from local fishermen at Dammam, Saudi Arabia.

\subsection{Separation of Exoskeleton Away from Muscles}

Fresh whole bodies of all samples of crustaceans were stored at $-20^{\circ} \mathrm{C}$ to facilitate peeling process after thawing when needed as most crustaceans. While, internal shell of Sepia and the carapace of $C$. edule were removed from 
edible muscles. The carapace of all samples dried in an oven for 6 hours at $105^{\circ} \mathrm{C}$ and then burn in a muffle furnace for 16 hours at $550^{\circ} \mathrm{C}$ till reduced to ash[16].

\subsection{Biochemical Analysis}

Powered samples were analyzed for carbohydrates [17], total proteins [18] and total lipids [19] and all values were expressed on percentage dry weight basis.

For analysis heavy metals, the obtained white ash was digested by $1 \mathrm{ml}$ of mixture of concentrated nitric acid (2/3) and concentrated perchloric acid (1/3; Merck). It was then dissolved in $1 \mathrm{ml}$ of 1:1000 dilute nitric acid and analyzed for heavy metals concentrations $(\mathrm{Cu}, \mathrm{Fe}, \mathrm{Co}, \mathrm{Cd}, \mathrm{Hg}, \mathrm{Pb})$ by using Perkin Elmer analyst 800 atomic absorption spectrophotometer with flow injection analysis system (FIAS) [20].

\subsection{Statistical Analysis}

The results of the present work were analyzed statistically by using the Statistical Package for Social Science (SPSS statistics version 15 package software). Data were expressed as Mean \pm S.E. Two way analysis of variance (ANOVA) was applied to illustrate the effect species and their interaction on the studied biochemical parameters.

\section{Results}

\subsection{Total Protei, Carbohydrates and Lipid Percentage}

The biochemical compositions of carapace of the studied crustaceans and mollusks species are illustrated in Table 1. Regarding with crustaceans species the data recoded that, the highest mean concentration of carbohydrates was observed in carapace of females E. massavensis from Ismailia and Suez regions (1.54\% and $1.50 \%$ respectively), whereas males of $P$. semisulcatus from Red Sea had the lowest level (0.94\%). Furthermore, the present data show that all females crustaceans had higher carbohydrates level in their exoskeleton than their males except $M$. monoceros $(1.05 \%)$ from the Arabian Gulf. Additionally, carbohydrates had this arrangement mantis shrimps $>$ crab species $>$ shrimps.

While, the highest mean value of protein was detected in males E. massavensis from both studied regions (42.98 and $45.45 \%$ from Suez and Ismailia respectively) and the lowest protein percentage was observed in males $P$. semisulcatus $(22.67 \%)$. Moreover, the present data declare that all carapace of females crustaceans except $E$. massavensis had higher content of protein than that of their males. Also, it was observed that, both sex of crab species had higher concentration of protein in their shells than that in shrimps species so, the protein level had the same arrangement as in carbohydrates content.

Unlike, protein the lowest mean value of lipid was recorded in the shells of both sexes of crab species compared to mantis shrimps and shrimps species, whereas the lowest level was noticed in males $P$. pelagicus from Red Sea $(8.80 \%)$. While, the maximum percentage of lipids was detected in males E. massavensis ( had $14.77 \%$ and $13.55 \%$ from Ismailia and Suez regions respectively). So, this order was observed mantis shrimps $>$ shrimps $>$ crabs. Furthermore, the results showed that all males crustaceans except crab species had the higher level of lipid than their females.

In mollusks species the present data in Table 1, show that all internal shells of studied cephalopods species had the higher carbohydrates, protein and lipid percentages than those of bivalves species. Furthermore, in comparison with the biochemical components of crustaceans species it was observed that carbohydrates exhibited the following decreasing order E. massavensis $>$ both strains of $P$. pelagicus $>$ both strains of Sepia spp. $>$ shrimps species $>$ both strains of $C$. edule. While protein percentage had this following arrangement E. massavensis $>$ both strains of Sepia spp. $>$ both strains of $P$. pelagicus $>$ shrimps species $>$ C.edule. Moreover, lipid showed this order all mantis shrimps $>$ shrimps species $>$ cephalopods mollusks $>$ crabs species $>$ bivalves mollusks.

\subsection{Heavy Metals Analysis}

Results for determined essential and non-essential heavy metals in exoskeletons of crustaceans species are given in Tables (2\&3). Generally, there were great variation in bioaccumulation of heavy metals between and among the location studied and sex of studied species. The carapace in both sexes of mantis shrimps E. massavensis from both studied regions accumulated higher percentages of the determined metals comparable to those of other studied crustaceans species in this study. On the other hand, the lowest level of $\mathrm{Fe}$ was recorded in both sex of crab from Red Sea $(61.21$ and $64.72 \mathrm{mg} / \mathrm{kg}$ for male and female respectively). Furthermore, the present results show that, both sex of crab species from two studied regions had the lowest mean values of $\mathrm{Cu}$ and $\mathrm{Co}$ compared to other crustaceans organisms. Additionally, those of female Red Sea strain of $P$. pelagicus had the lowest values for $\mathrm{Hg}(6.30$ $\mathrm{mg} / \mathrm{kg}$ ). While, carapace of females $P$. semisulcatus shrimps bioaccumulated lowest level of $\mathrm{Pb}$ and $\mathrm{Cd}(7.15 \mathrm{mg} / \mathrm{kg}$ and $0.28 \mathrm{mg} / \mathrm{kg}$ respectively).

Regarding with the contents of studied heavy metals in carapace of cephalopods and bivalves mollusks the present results represented in Tables $2 \& 3$, indicate that Sepia spp. exhibited the lowest levels of the determined essential and non-essential metals comparable to $C$. edule species. Furthermore, it was noticed that the internal shell of Sepia from Red Sea and the Arabian Gulf had the lowest levels of $\mathrm{Cu}(1.90$ and $2 \mathrm{mg} / \mathrm{kg}$ respectively), Co (1.57 and 2.14 $\mathrm{mg} / \mathrm{kg}$ respectively), $\mathrm{Hg}$ (5.30 and $6.03 \mathrm{mg} / \mathrm{kg}$ respectively) and $\mathrm{Cd}(0.167$ and $0.183 \mathrm{mg} / \mathrm{kg}$ respectively) comparable to those of crustaceans species. On the other hand, the exoskeleton of $C$. edule from two studied regions accumulated the higher concentrations of $\mathrm{Fe}, \mathrm{Co}, \mathrm{Pb}$ and $\mathrm{Cd}$ than those in all studied crustaceans species. 
To compare the total metal content in shell of different sampling organisms investigated in this study, the metal pollution index (MPI) was used (Table 4). The recorded data showed that the mean values of MPI of essential metals (ranged from 2.42 to 8.85 ) were higher than that of non-essential metals (ranged from1.42 to 2.46 ) in all studied marine organisms. Moreover, the highest mean values of MPI of essential trace metals were recorded in both sexes of E. massavensis in two studied areas, while the lowest levels were detected in Sepia from Red sea (2.42) and from the Arabian Gulf (2.56) . Furthermore, all C. edule strains had the highest level of MPI of non- essential metals ( 2.22 and 2.46 from Red Sea and Arabian Gulf respectively) while, the lowest values were recorded in Sepia Red Sea strain and Arabian Gulf strain (1.38 and 1.43 respectively).

\section{Discussion}

Marine invertebrates organisms, particularly edible species of crustaceans and mollusks have been intensely investigated and used as model organisms in a number of studies on biochemical composition and nutritive quality [2- 5, 10, 21-24]. On the other hand limited studies were focused on the biochemical components of exoskeleton of marine organisms [6, 22-24]. However, the dried carapace can act as a rich constituent of poultry food $[2,4,22]$. Furthermore, the seafood processing industry is not well known in our country, Egypt, but it is one of the major food processing industries in India. In the years 2003 to 2004, 129,785 tones of frozen shrimps were produced [25]. Processing of shrimps invariably generates solid waste (body carapace). The waste generation from processing of Indian shrimps ranges from 48 to $56 \%$ of the total weight depending on the species [26]. This solid waste contains many valuable compounds that after appropriate processing can add substantially to overall profitability. This biomaterial can be valorized without fractionation, usually it is applied as such for feeding in veterinary practice and aquaculture. Medium and large scale processing has been developed to dry the waste and to mix it with other agricultural raw materials to produce animal feed [3, 27]. So, the evaluation of the nutritive quality of shells of commercially crustaceans and mollusks has a concern to open the door for production a new products of nutraceutical healthy food for animal consumption.

The data of the present study show that the exoskeleton of males and females E. massavensis from studied areas had the highest content of carbohydrates and protein compared to other crustaceans and mollusks. Additionally, their males contained the highest level of lipid. Therefore, from the present work, in terms of nutritive quality $E$. massavensis could be considered the richest crustaceans as animal feed followed by Sepia and crabs then the two shrimp species ( $P$. semisulcatus and $M$. monoceros) and bivalves mollusks according to their protein content. This results ranked E. massavensis as the first rich edible crustaceans which drew the attention to the need of considering this protein rich crustaceans as good competitor among its economic counterparts in Mediterranean area. In this respect, many studies were done on the edible muscles of E. massavensis and indicated the presence of high amount of protein [4-6, 28]. Nevertheless, the recorded values of carbohydrates, protein and lipid in the carapace of the mantis shrimps in the present study were less than those recorded in their edible muscles $[5,6]$. Furthermore, the present result demonstrate that the exoskeleton of males E. massavensis from two studied localities had higher percentage of protein than females. Similarly, the relatively high percentage of protein in edible muscles of males compared to females in commercial crustaceans was reported in other studies on Procambrius clarki and E. massavensis [5, 6, 24]. The elevation of protein content in males decapods crustaceans than in females indicates a faster growth rate in males as compared to females $[24,28,29]$. The present result do not confirm this opinion due to the carapace of female shrimps and crabs in the present work had higher protein content in their shells than that of their males. Therefore, the estimation of chemical composition of edible muscles of these marine organisms should be carried out. Another explanation attributed the high protein content to stress conditions caused by toxicity of heavy metals on protein metabolism or due to enhanced proteolytic activity as a consequence of increased metabolic demands following exposure to toxic pollutants in the aquatic environment as suggested by [30]. The present study does not agree with this suggestion, since the present data shown that $C$. edule was the most vulnerable to metal accumulation comparable to other studied species and in the same time had the lowest protein content.

Metal pollution of the sea is less visible and direct than other types of marine pollution, but its effects on marine ecosystems are intensive and very extensive[10]. As indirect measure of the abundance and availability of metals in the marine environment, the bioaccumulation of metals by the tissues of marine organisms had been studied [31-33]. The bioaccumulation studies led to adoption of the bioindicators concept, so seafood is widely used as bio-indicators of marine pollution by metals [34]. Therefore the present study was carried out to measure mean concentration of six heavy metals ; $\mathrm{Fe}, \mathrm{Cu}, \mathrm{Co}, \mathrm{Hg}, \mathrm{Pb}$ and $\mathrm{Cd}$, in shells of studied marine organisms to ensure the safety of these shells as a animal food as well as to determine the interrelation of shells of marine organisms and water pollution.

The data of the present study show that the average concentrations of determined heavy metals in carapace of studied organisms exhibited the following decreasing order bivalve $>$ mantis shrimps $>$ shrimps $>$ crabs $>$ cephalopods for $\mathrm{Fe}, \mathrm{Pb}$ and $\mathrm{Cd}$. This arrangement was not in accordance with the results of [10] who reported the following arrangement of metal bioaccumulation $(\mathrm{Cu}, \mathrm{Fe}, \mathrm{Hg}, \mathrm{Pb}$ and $\mathrm{Cd}$ ) in edible muscles in Mediterranean Sea species : cephalopods $>$ bivalve $>$ crustacean. According to MPI, the 
present results showed that, Sepia and crab had the lowest MPI of essential and non-essential metals, while $E$. massavensis had the highest MPI of essential metals and $C$. edule had the highest MPI of non-essential metals. This is not agreeing with the results of [10] which showed that MPI in essential and non-essential metals recorded higher values in edible muscles of Sepia followed by crustaceans (shrimps and crabs) followed by bivalve mollusks.

Table 1: Total percentages of the biochemical constituents of male and female shell's crustaceans and mollusks species in the studied regions.

\begin{tabular}{|c|c|c|c|c|c|c|c|}
\hline \multirow{2}{*}{ Species } & \multirow{2}{*}{ Region } & \multicolumn{2}{|c|}{ Carbohydrates (\%) } & \multicolumn{2}{|c|}{ Protein (\%) } & \multicolumn{2}{|c|}{ lipids (\%) } \\
\hline & & Males & Females & Males & Females & Males & Females \\
\hline E. massavensis & Suez & $1.38 \pm 0.00^{\mathrm{cd}}$ & $1.50 \pm 0.00^{\mathrm{a}}$ & $42.98 \pm 1.81^{\mathrm{b}}$ & $37.50 \pm 0.99^{c}$ & $13.55 \pm 0.08^{\mathrm{ab}}$ & $9.90 \pm 0.05^{\mathrm{e}}$ \\
\hline E. massavensis & Ismailia & $1.45 \pm 0.00^{\mathrm{ab}}$ & $1.54 \pm 0.00^{\mathrm{a}}$ & $45.45 \pm 1.55^{\mathrm{a}}$ & $36.99 \pm 0.72^{\mathrm{c}}$ & $14.77 \pm 0.01^{\mathrm{a}}$ & $10.44 \pm 0.02^{\mathrm{de}}$ \\
\hline P. semisulcatus & Red Sea & $0.94 \pm 0.01^{\mathrm{g}}$ & $1.14 \pm 0.01^{\mathrm{f}}$ & $22.67 \pm 0.19^{j}$ & $27.33 \pm 0.06^{\mathrm{h}}$ & $11.57 \pm 0.05^{\mathrm{c}}$ & $10.62 \pm 0.14^{\mathrm{d}}$ \\
\hline M. monoceros & Arabian Gulf & $1.21 \pm 0.013^{\mathrm{e}}$ & $1.05 \pm 0.03^{\mathrm{f}}$ & $23.84 \pm 0.09^{\mathrm{i}}$ & $26.82 \pm 0.13^{\mathrm{h}}$ & $12.76 \pm 0.08^{\mathrm{b}}$ & $12.53 \pm 0.04^{b}$ \\
\hline P. pelagicus & Red Sea & $1.27 \pm 0.02^{\mathrm{de}}$ & $1.33 \pm 0.03^{\mathrm{d}}$ & $30.84 \pm 0.17^{\mathrm{f}}$ & $29.91 \pm 0.05^{\mathrm{g}}$ & $8.80 \pm 0.06^{\mathrm{i}}$ & $9.44 \pm 0.10^{\mathrm{fg}}$ \\
\hline P. pelagicus & Arabian Gulf & $1.37 \pm 0.02^{\mathrm{cd}}$ & $1.40 \pm 0.01^{\mathrm{bc}}$ & $32.67 \pm 0.17^{\mathrm{e}}$ & $36.55 \pm 0.17^{\mathrm{c}}$ & $9.17 \pm 0.09^{\mathrm{g}}$ & $9.82 \pm 0.0 .04^{\text {eh }}$ \\
\hline Sepia spp. & Red Sea & \multicolumn{2}{|c|}{$1.24 \pm 0.02^{\mathrm{e}}$} & \multicolumn{2}{|c|}{$36.95 \pm 0.05^{\mathrm{c}}$} & \multicolumn{2}{|c|}{$10.83 \pm 0.14^{\mathrm{d}}$} \\
\hline Sepia spp. & Arabian Gulf & \multicolumn{2}{|c|}{$1.22 \pm 0.02^{\mathrm{e}}$} & \multicolumn{2}{|c|}{$34.41 \pm 0.32^{\mathrm{d}}$} & \multicolumn{2}{|c|}{$9.61 \pm 0.20^{\text {fh }}$} \\
\hline C. edule & Red Sea & \multicolumn{2}{|c|}{$0.82 \pm 0.01^{\mathrm{h}}$} & \multicolumn{2}{|c|}{$18.53 \pm 0.42^{\mathrm{k}}$} & \multicolumn{2}{|c|}{$4.18 \pm 0.08^{j}$} \\
\hline C. edule & Arabian Gulf & \multicolumn{2}{|c|}{$0.78 \pm 0.02^{\mathrm{i}}$} & \multicolumn{2}{|c|}{$16.80 \pm 0.13^{1}$} & \multicolumn{2}{|c|}{$3.14 \pm 0.05^{\mathrm{k}}$} \\
\hline $\begin{array}{c}\text { ANOVA } \\
\text { (Species effect }\end{array}$ & & \multicolumn{2}{|c|}{$F=101.700$} & \multicolumn{2}{|c|}{$F=739.507$} & \multicolumn{2}{|c|}{$F=690.270$} \\
\hline
\end{tabular}

Data are expressed as means \pm S.E. of five separated determinations; means marked with the same letter for each parameters are not significantly different $(\mathrm{P}>0.05)$, otherwise they do.

Table 2: $\mathrm{Fe}, \mathrm{Cu}$ and Co concentrations $(\mathrm{mg} / \mathrm{kg})$ in shells of males and females crustaceans and mollusks species in the studied regions .

\begin{tabular}{|c|c|c|c|c|c|c|c|}
\hline \multirow{3}{*}{ Species } & \multirow{3}{*}{ Region } & \multicolumn{2}{|c|}{$\mathrm{Fe}$} & \multicolumn{2}{|c|}{$\mathbf{C u}$} & \multicolumn{2}{|c|}{ Co } \\
\hline & & \multicolumn{2}{|c|}{$P I=35$} & \multicolumn{2}{|c|}{$\mathbf{P l}=\mathbf{3 0}$} & \multicolumn{2}{|c|}{$\mathbf{P l}=\mathbf{3 0}$} \\
\hline & & Males & Females & Males & Females & Males & Females \\
\hline $\begin{array}{c}\text { E. } \\
\text { massavensis }\end{array}$ & Suez & $180.66 \pm 1.40 \mathrm{de}$ & $177.55 \pm 1.02 \mathrm{e}$ & $133 \pm 2.55 b$ & $190 \pm 3.22 \mathrm{a}$ & $13.40 \pm 0.39 \mathrm{~d}$ & $14.22 \pm 0.18 \mathrm{c}$ \\
\hline $\begin{array}{c}\text { E. } \\
\text { massavensis }\end{array}$ & Ismailia & $186.00 \pm 3.00 \mathrm{c}$ & $183.00 \pm 0.95 \mathrm{~d}$ & $135 \pm 0.39 b$ & $193 \pm 1.55 \mathrm{a}$ & $12.66 \pm 1.14 \mathrm{~d}$ & $12.87 \pm 1.56 \mathrm{~d}$ \\
\hline $\begin{array}{c}\text { P. } \\
\text { semisulcatus }\end{array}$ & Red Sea & $121.0 \pm 0.56 \mathrm{~g}$ & $141.65 \pm 1.25 \mathrm{f}$ & $54.92 \pm 0.74 d$ & $48.60 \pm 0.87 f$ & $9.15 \pm 0.02 \mathrm{f}$ & $10.67 \pm 0.17 \mathrm{e}$ \\
\hline M. monoceros & Arabian Gulf & $85.66 \mathrm{~d} \pm 0.88 \mathrm{i}$ & $96.90 \pm 1.50 \mathrm{~h}$ & $73.33 \pm 0.34 c$ & $39.06 \pm 0.53 \mathrm{~g}$ & $12.51 \pm 0.03 \mathrm{~d}$ & $7.71 \pm 0.15 \mathrm{~g}$ \\
\hline P. pelagicus & Red Sea & $61.21 \pm 0.61 \mathrm{k}$ & $64.72 \pm 0.89 \mathrm{k}$ & $3.36 \pm 0.81 \mathrm{i}$ & $4.30 \pm 0.40 \mathrm{~h}$ & $3.26 \pm 0.03 \mathrm{~h}$ & $2.32 \pm 0.02 \mathrm{j}$ \\
\hline P. pelagicus & Arabian Gulf & $120.56 \pm 0.38 \mathrm{~g}$ & $121.70 \pm 0.89 \mathrm{~g}$ & $4.13 \pm 1.73 \mathrm{hi}$ & $4.63 \pm 0.18 \mathrm{~h}$ & $3.74 \pm 0.01 \mathrm{hi}$ & $3.56 \pm 0.03 \mathrm{i}$ \\
\hline Sepia spp. & Red Sea & \multicolumn{2}{|c|}{$67.72 \pm 0.89 \mathrm{j}$} & \multicolumn{2}{|c|}{$1.90 \pm 0.01 \mathrm{j}$} & \multicolumn{2}{|c|}{$1.57 \pm 0.02 \mathrm{k}$} \\
\hline Sepia spp. & Arabian Gulf & \multicolumn{2}{|c|}{$69.80 \mathrm{a} \pm 0.42 \mathrm{j}$} & \multicolumn{2}{|c|}{$2.00 \pm 0.01 \mathrm{j}$} & \multicolumn{2}{|c|}{$2.14 \pm 0.01 \mathrm{j}$} \\
\hline C. edule & Red Sea & \multicolumn{2}{|c|}{$224.53 \pm 0.74 a$} & \multicolumn{2}{|c|}{$53.12 \pm 0.48 \mathrm{e}$} & \multicolumn{2}{|c|}{$23.7 \pm 0.14 a$} \\
\hline C. edule & Arabian Gulf & \multicolumn{2}{|c|}{$205.29 \pm 1.19 b$} & \multicolumn{2}{|c|}{$55.80 \pm 0.12 d$} & \multicolumn{2}{|c|}{$22.1 \pm 0.06 b$} \\
\hline \multicolumn{2}{|c|}{ ANOVA 4} & \multicolumn{2}{|c|}{$F=3063.693$} & \multicolumn{2}{|c|}{$F=19784.136$} & \multicolumn{2}{|c|}{$F=7242.610$} \\
\hline \multicolumn{2}{|c|}{ (Species effect) } & \multicolumn{2}{|c|}{$\mathrm{P}<0.000$} & \multicolumn{2}{|c|}{$\mathrm{P}<0.000$} & \multicolumn{2}{|c|}{$\mathrm{P}<0.000$} \\
\hline
\end{tabular}

Data are expressed as means \pm S.E. of five separated determinations; means marked with the same letter for each parameters are not significantly different $(\mathrm{P}>0.05)$, otherwise they do. $\mathrm{Pl}=$ permissible limit according to [38]. 
Hala Ali Abdel-Salam: Assessment of Biochemical Compositions and Mineral Contents of Carapace of Some Important Commercially Crustaceans and Mollusks Organisms from Egyptian and Saudi Arabia Coasts as a New Animal Feed

Table 3. $\mathrm{Hg}, \mathrm{Pb}$ and $\mathrm{Cd}$ concentrations $(\mathrm{mg} / \mathrm{kg})$ in shells of males and females crustaceans and mollusks species in the studied regions.

\begin{tabular}{|c|c|c|c|c|c|c|c|}
\hline \multirow{3}{*}{ Species } & \multirow{3}{*}{ Region } & \multicolumn{2}{|c|}{$\mathbf{H g}$} & \multicolumn{2}{|c|}{$\mathbf{P b}$} & \multicolumn{2}{|c|}{ Cd } \\
\hline & & \multicolumn{2}{|c|}{$\mathrm{Pl}=5$} & \multicolumn{2}{|c|}{$\mathrm{Pl}=0.5$} & \multicolumn{2}{|c|}{$\mathrm{Pl}=0.5$} \\
\hline & & Males & Females & Males & Females & Males & Females \\
\hline E. massavensis & Suez & $10.00 \pm 0.15^{\mathrm{a}}$ & $9.96 \pm 0.21^{\mathrm{a}}$ & $13.00 \pm 0.23^{\mathrm{a}}$ & $11.43 \pm 0.01^{\mathrm{b}}$ & $0.80 \pm 0.01^{\mathrm{a}}$ & $0.68 \pm 0.01^{\mathrm{a}}$ \\
\hline E. massavensis & Ismailia & $9.99 \pm 0.55^{\mathrm{a}}$ & $10.01 \pm 0.34^{\mathrm{a}}$ & $11.02 \pm 0.03^{\mathrm{bc}}$ & $10.66 \pm 0.43^{\mathrm{c}}$ & $0.75 \pm 0.01^{\mathrm{a}}$ & $0.66 \pm 0.01^{\mathrm{a}}$ \\
\hline P. semisulcatus & Red Sea & $7.43 \pm 0.20^{\mathrm{def}}$ & $7.57 \pm 0.24^{\mathrm{d}}$ & $9.50 \pm 0.08^{\mathrm{e}}$ & $7.15 \pm 0.03^{\mathrm{h}}$ & $0.65 \pm 0.01^{\mathrm{a}}$ & $0.28 \pm 0.02^{\mathrm{a}}$ \\
\hline M. monoceros & Arabian Gulf & $9.80 \pm 0.44^{\mathrm{ab}}$ & $9.95 \pm 0.58^{\mathrm{a}}$ & $7.12 \pm 0.00^{\mathrm{h}}$ & $7.71 \pm 0.04^{\mathrm{g}}$ & $0.48 \pm 0.01^{\mathrm{a}}$ & $0.43 \pm 0.00^{\mathrm{a}}$ \\
\hline P. pelagicus & Red Sea & $7.90 \pm 0.06^{\mathrm{d}}$ & $6.30 \pm 0.21^{\mathrm{f}}$ & $10.33 \pm 0.06^{\mathrm{c}}$ & $8.21 \pm 0.07^{\mathrm{f}}$ & $0.39 \pm 0.01^{\mathrm{a}}$ & $0.40 \pm 0.01^{\mathrm{a}}$ \\
\hline P. pelagicus & Arabian Gulf & $6.47 \pm 0.24^{\mathrm{fg}}$ & $6.81 \pm 0.14^{\mathrm{efg}}$ & $9.87 \pm 0.07^{\mathrm{d}}$ & $9.92 \pm 0.01^{\mathrm{d}}$ & $0.36 \pm 0.02^{\mathrm{a}}$ & $0.37 \pm 0.02^{\mathrm{a}}$ \\
\hline Sepia spp. & Red Sea & \multicolumn{2}{|c|}{$5.30 \pm 0.12^{\mathrm{h}}$} & \multicolumn{2}{|c|}{$7.93 \pm 0.04^{\mathrm{f}}$} & \multicolumn{2}{|c|}{$0.17 \pm 0.01^{\mathrm{a}}$} \\
\hline Sepia spp. & Arabian Gulf & \multicolumn{2}{|c|}{$6.04 \pm 0.04^{\mathrm{g}}$} & \multicolumn{2}{|c|}{$7.62 \pm 0.13^{\mathrm{fg}}$} & \multicolumn{2}{|c|}{$0.18 \pm 0.01^{\mathrm{a}}$} \\
\hline C. edule & Red Sea & \multicolumn{2}{|c|}{$9.10 \pm 0.15^{\mathrm{bc}}$} & \multicolumn{2}{|c|}{$12.75 \pm 0.23^{\mathrm{a}}$} & \multicolumn{2}{|c|}{$1.04 \pm 0.01^{\mathrm{a}}$} \\
\hline C. edule & Arabian Gulf & \multicolumn{2}{|c|}{$8.85 \pm 0.10^{\mathrm{c}}$} & \multicolumn{2}{|c|}{$13.13 \pm 0.19^{\mathrm{a}}$} & \multicolumn{2}{|c|}{$1.91 \pm 0.05^{\mathrm{a}}$} \\
\hline \multicolumn{2}{|c|}{ ANOVA 4} & \multicolumn{2}{|c|}{$F=33.422$} & \multicolumn{2}{|c|}{$F=409.767$} & \multicolumn{2}{|c|}{$\mathrm{F}=1.655$} \\
\hline \multicolumn{2}{|c|}{ (Species effect) } & \multicolumn{2}{|c|}{$\mathrm{P}<0.0001$} & \multicolumn{2}{|c|}{$\mathrm{P}<0.0001$} & \multicolumn{2}{|c|}{$\mathrm{P}>0.05$} \\
\hline
\end{tabular}

Data are expressed as means \pm S.E. of five separated determinations; means marked with the same letter for each parameters are not significantly different $(\mathrm{P}>0.05)$, otherwise they do. $\mathrm{Pl}=$ permissible limit according to [38]

Table 4:Metal pollution index(MPI)in the shell of crustaceans and mollusks species.

\begin{tabular}{|c|c|c|c|c|c|}
\hline \multirow{3}{*}{ Species } & \multirow{3}{*}{ Region } & \multicolumn{4}{|c|}{ MPI factor } \\
\hline & & \multicolumn{2}{|c|}{ Essential elements } & \multicolumn{2}{|c|}{$\begin{array}{c}\text { Non-essential } \\
\text { elements }\end{array}$} \\
\hline & & Males & Females & Males & Females \\
\hline $\begin{array}{c}E . \\
\text { massavensis }\end{array}$ & Suez & 8.28 & 8.85 & 2.17 & 2.06 \\
\hline $\begin{array}{c}E . \\
\text { massavensis }\end{array}$ & Ismailia & 8.15 & 8.77 & 2.09 & 2.03 \\
\hline $\begin{array}{c}P . \\
\text { semisulcatus }\end{array}$ & Red Sea & 6.27 & 6.47 & 1.89 & 1.57 \\
\hline $\begin{array}{c}M . \\
\text { monoceros }\end{array}$ & $\begin{array}{c}\text { Arabian } \\
\text { Gulf }\end{array}$ & 6.55 & 5.48 & 1.80 & 1.79 \\
\hline P. pelagicus & Red Sea & 2.96 & 2.94 & 1.78 & 1.66 \\
\hline P. pelagicus & Red Sea & 3.51 & 3.55 & 1.69 & 1.71 \\
\hline Sepia spp. & Red Sea & & & & \\
\hline Sepia spp. & $\begin{array}{c}\text { Arabian } \\
\text { Gulf }\end{array}$ & & & & \\
\hline C. edule & Red Sea & & & & \\
\hline C. edule & $\begin{array}{c}\text { Arabian } \\
\text { Gulf }\end{array}$ & & & & \\
\hline
\end{tabular}

MPI $=\left(M_{1 \times} M_{2 \times} M_{3 X} \ldots . X M_{n}{ }^{1 / n}\right.$, where $M_{n}$ is the concentration expressed in $\mathrm{mg} / \mathrm{kg}$ of any investigated metals according to [10].
In this respect, concerning with concentrations of determined heavy metal in shells of crustaceans and mollusks species in the present work it was observed that the levels of determined essential and non-essential metals were greater in values compared to their levels in edible muscles as recorded by other studies $[5,6,10,33,35,36]$. Furthermore, previously [36] recorded that most of the Co body burden of male shore crabs Carcinus maenas was located in their exoskeleton (45\%) comparable to muscles. Additionally, [37] showed that the cuticle of Squilla mantis from the Gulf of C' aidz accumulated the highest levels of essential and non-essential elements compared to their muscles. Generally metal contaminations in the marine organisms can pose a health risk to the aquatic organisms themselves, to the predators and to organism who consume them when the bioaccumulated metals above the risk international standards. In this study, according to the safe limit which reported by [38] for metals concentrations of heavy metals, it was recorded that the concentrations of Co in all studied organisms were below the allowable limit. On the other hand, the levels of $\mathrm{Cu}$ exceeded the permissible limits in all studied species except in crab and cephalopods. Furthermore, the concentrations of $\mathrm{Fe}, \mathrm{Hg}$ and $\mathrm{Pb}$ in all studied species were above the permissible limit. While, $\mathrm{Cd}$ content was higher than the allowable limit in both sexes of E. massavensis, males $P$. semisulcatus and in $C$. edule strains. The accumulation of heavy metals in the shells gives a strong indication of high levels of metals exposure, so the shells of marine organisms can be used as an indicator of water pollution and this suggest their tendency to detoxification mechanism of heavy metals as a mean of protection. In this respect, studies of $[39,40]$ showed that 
the carapace of the crab, a waste materialdisposed of by the seafood industry potential as a bio -sorbent for the removal of metals from aqueous medium. From that it is concluded that if the coastal pollution has reached significant levels causing a threat for life forms in the seas and Gulfs so that consumption of non-edible portion of the marine organisms should be avoided since it is a direct source of metal intoxication. This in agreement with the present study in that E. massavensis collected from Suez which bioaccumulated the highest levels of heavy metals compared to other studied crustaceans samples. This may attributed to that El- Suez harbor at inlet of Suez Canal in Mediterranean Sea with its dense ships traffic receives several types of hazardous chemical pollutants affecting dramatically its water. Therefore, the results of the present study are in agreement with the results of [4-6] in that $E$. massavensis can be used as a bioindicator of water pollution. As the result of the data of the present study suggested that, among the studied crustaceans species, mantis shrimps are the most vulnerable to metal pollution. They could be more vulnerable because they exposed to metals not only from the sediment, in which they dig their burrows, or from the surrounding water ,but also through prey consumption. Accumulation of trace metals in aquatic organisms has been correlated to their feedings habits [41]. Mantis shrimps are known to be obligate carnivores, feeding only on live prey [42]. Those of the Mediterranean have been reported to show a preference towards penaeid shrimps [35] .Since, E. massavensis and C. edule has been recorded to accumulate the highest concentrations of heavy metals in their exoskeleton, it seems necessary to carry out an eco-toxicological assessment of these metals in their edible muscles in order to establish the relationship between the body load of this species contamination and the potential toxiceffects so as to derive tissue quality values.

\section{Conclusion}

In conclusion, the present work revealed that the exoskeleton of E. massavensis, P. semisulcatus, $M$. monoceros, and P. pelagicus and the internal shell of Sepia can be ground and used for formulating animal feed as they contain considerable amounts of protein and moderate amount of carbohydrates and lipids higher than in C.edule . Bioaccumulation patterns of metals in marine organisms can be utilized as effective indicators of environmental metal contamination also, carapaces of crustaceans and mollusks organisms can be used for monitoring potential risk to humans. Moreover, further studies on the mode of action and characterization of the active components in these crustaceans and mollusks species must be done to open the door in the future to use these species as specific health foods (functional supplements as antioxidant agents) and to play an important role in some pharmaceutical industries. Furthermore, the present study suggest the possibility of using the carapace of marine invertebrates especially, those of mantis. shrimps and bivalve mollusks as bioindicator of water pollution. This in turn suggests that a close monitoring program is need to ensure the safety of these crustacean and mollusks species as a food source for our animal. On the whole, the collection of such crustaceans and mollusks should be restricted to clean aquatic habitats whether these natural water or water cultures, a protective measure that also applies in consuming all other aquatic seafood fauna.

\section{Acknowledgement}

Sincere gratitude is expressed to Deanship of Scientific Research, Majmaah University, Saudi Arabia for the financial support, fruitful cooperation and continuous help throughout this work.

\section{References}

[1] C, BRANDI, "The importance of a shell for crustaceans and mollusks", 200 Brickstone Square Andover, , MA01810 USA, 2007.

[2] F.A.R., Ehigiator and E.A., Oterai,., "Chemical Composition \& Amino Acid Profile of a Caridean Prawn". IJRRAS, 11 (1):162-166, 2012.

[3] Roy, E. Martin, George J. Flick, , John Wiley \& SONS, "Composition of the Edible Portion of Raw(Fresh or Frozen) Crustaceans, Finfish, and Mollusks. II Macroelements: Sodium, Potassium, Chlorine Calcium, Phosphorus, and Magnesium. Species, Products, Processing, and Safety" ISBN: 1118229533, 9781118229538, 2012.

[4] W.S., Sallam, T. A ., Temraz,. and , H. R., Gabar "Biochemical compositions and heavy metals accumulation in some commercial crustaceans from the Mediterranean coast off Port Said, Egypt”. J. Egypt. Ger. Soc. Zool. 51 D: 127-14, 2006.

[5] H.A .,Abdel-Salam, and A.H. S, Hamdi, "Bio chemical compositions and heavy metals accumulation capacity of the of the marine mantis shrimp Erugosquilla massavensis from the Suez canal(El- Suez and Ismailia) " . J. Egypt. Germ. Soc. ZOO., 61:199-214, 2011.

[6] S. A. H ., HAMDI, "Muscle and exoskeleton extracts analysis of both fresh and marine crustaceans $P$. clarki and $E$. massavensis. African” J. Pharm. 5(13):1589-1597, 2011.

[7] S. A. H ., Hamdi, "Heavy metal bioaccumulative capacity of the Red Swamp Crawfish $P$. clarki in the river Nile, Egypt" J. Union Arab . Biol. .Cairo, 20(A): 177-199.(2004).

[8] N., Dennis, J. H ., Pourang, And H. Ghourchian "Distribution of heavy metals in Penaeus Semisulcatus from Persian Gulf and possible role of metallothionein in their redistribution during storage". Environ. Montr. Assess100(1:3)71-81, 2005.

[9] A., K., Abou Arab, A.M., Ayesh, H. A. ,Amra, and K., ,Naguib, "Characteristic levels of some pesticides and heavy”,1996, Food Chem., 57(4): 478-492, 1996.

[10] H., Ahdy, Abd Allah, A. and F., Tayel, "Assessment of the 
heavy metals and non-essential content of some edible and soft tissues". Egypt Aqua. Res. 33(1)85-97, 2007.

[11] R.B., Clark, Marine pollution. $2^{\text {nd }}$ edition Oxford, 1989.

[12] K., Sullivan, , "Vitamins and Minerals: A Practical approach to a health diet and safe supplementation". Harper Collins. copper development dissociation. 5 Grovelands Business Centre Boundary Way Hemel Hempstead · HP2 7TE - United Kingdom. Email: info@copperalliance.org.uk, 2002.

[13] M., Abdullah, and J., Chmielnicka, "New Aspects on the distribution and metabolism of essential trace elements after dietary exposure to toxic metals". Bio. Trace. Element Rese. $23: 25-53,1990$

[14] J. P., Groten, and V., Bladeren, "Cadmium bioavailability and health risk in food". Trends in food Science \& Techn. 5: 50-55 ( 1994)

[15] M., Kalay, O., Aly, and M., Canil, "Heavy metal concentrations in fish tissues from the Northeast concentrations in fish tissues. Mediterranean Sea". Bull. Environ. Contam. Toxic. Pollut., 133(3): 481-487(1999)

[16] V.D. ,Sidwell, B. R. ., Stillings, and G.M, Knobl, "The fish protein concentrations.10- Nutrition quality and use in foods",1970 . J. Food Technol.,14(8):40-46.

[17] O.H., Lawery, W.H., Daughaday, N.J, Rosebroughady, and , W.S .,Field, "Determination of cerebral protein using Folinphenol reagent", J. lab. Clin Med.,39: 663-665, 1952.

[18] B.J. ,Barber, and N. J., Blanke, "Energy storage and utilization in relation to gametogenesis in Astropecten irradians". Exp. Mar. Biol. Eco.,52-1122-1134, 1981.

[19] D.L. ,Holland, and P.J., Hannant, "Addendum to a micro analytical scheme for the biochemical analysis of marine invertebrate larvae" J. Mar Biol. Ass. U.K. , 51:659-668, 1973.

[20] T., Larsen, and B., Sandstrom, , "Effect of dietary calcium level on mineral and trace element utilization from a rapeseed (Brassica napus L.) diet ileum -fistulated pigs". Br. J. Nutr.,69:211, 1993.

[21] R. , Rosa, and M.L, Nunes, "Biochemical changes in different tissues of the mantis shrimp, Oratoasquilla nepa stomatopoda) during reproductive cycle", Ind. J. Mar. Sci., 224, 2002.

[22] J.V., Huner, and J. E., BARR, , "Red swamp crawfish biology and exploitation", $3^{\text {rd }}$. Louisiana state Univ., Baton. Louisiana, 1991.

[23] H.M., Mona, S.N., Geasa, Sharshar, and M.K. M. E. Morsy, "Chemical composition of freshwater crayfish Erugosquilla massavensis and its nutritive values. Egypt" ,. J . aquatic. Biol. fish.,4(1):19-34, 2002.

[24] [ [24]. Soliman, G. N., El-Assal,F. ,Salah EL-Dine, M. and Hamdi, S,A.H: "Habitat, distribution and behavior of the red swamp crayfish Procambrus clarki in the River Nile, Egypt". Egypt. J. Zool., 30:297-310, 1998.

[25] [.MPEDA Marine export reviews", Available from www.mpeda.com(2004).

[26] N.M, Sachindra, N, Bhaskar, NS Mahendrakar, Recovery of carotenoids from shrimp waste in organic solvents". Waste Manag,26:1092-1098, ”, 2006.
[27] W. F. ,Stevens, P., Cheypratub, S., Haiqing, P., Lertsutthiwong,, S. , Chandrkrachang, "Bioprocess Technology Program Asian Institute of Technology, Bangkok Thailand", , $5^{\text {th }}$ Asian Fisheries Forum, ISBN 974-7578-02-6, 1998.

[28] R. C. , Sinha, and H. K. Ahmed, "Some changes in biochemical composition with sex and size of the crab Calman. Hydrobiologia, 61:15-19, 1978.

[29] A. F. , Hafez, , A., Abudl- Azziz, Z. M .A. Soliman, and M.H., Agouz, "Red swamp crayfish meal Procambarus clarkia and its by-product as alternative for fish meal in diets of Nile tilapia. Egypt", ,. J. Agric.Res., Nrc-1(1):209-223, 2003.

[30] P.S., Kharat, , L.B, R.S. GhobleKale, and B. C., Ghoble, "IMPACT of TBCC on total protein content in freshwater prawn, Macrobrachium istnensis". Middle East. J. Sci.. Res. , 4:180-184, 2009.

[31] N.P.C., Tu, N.N., Ha, T., Ikemoto , B.C., Tuyen Tanabe S., I .,Takeuchi, "Regional variations in trace element concentrations in tissues of black tiger shrimp Penaeus monodon from South Vietnam. Marine”. Bull.57:858-866, 2008.

[32] P., RAJA, "Heavy metals concentration in four commercially valuable marine edible fish species from Parangipettai Coast, South East Coast of India”. J. Animal \& Veter. Advan. 1(1): $10-14,2009$.

[33] C., Viswanathan, R., M.., Azhaguraj, M., Selvanayagam, and Raffi1, S.M "Heavy metal levels in different tissues of the Blue Swimming crab (Portunus pelagicus, Portunidae) collected from Ennore Estuary". Inter. J. f Res. Fish. Aquatic; 3(1): 1-6, 2013.

[34] , D.W., Evans, , D.K Dodoo. P.J., and Hanson, "Trace elements concentrations in fish livers implications of variations with fish size in pollution monitoring"( Mar. Pollut Bull., 26(6):29-34, 1993.

[35] W.S. ,SALLAM, "Feeding biology of the stomoatopod crustacean Erugosquilla massavensis from Port Said coast, Egypt". Proceeding of the Third International Conference on Biological Sciences. Tanta University, 2004.

[36] A., Bjerregaard, and M.., Depledge, "Trace metal concentrations and contents in the tissues of the shore crab Carcinus maenas: effects of size and tissue hydration". 2 Marine Bio.141(4):741-752, 2002.

[37] Blasco, J.,Arias, A.M and Saenz,V. "Heavy metals concentrations in Squilla mantis (Crustacea, Stomatopoda) from the Gulf of Ca'diz. Evaluation of the impact of the Aznaalcollar”. Environ. Inter., 28-111-116, 2002.

[38] FAO/ WHO Food, "Standards Programme Document - ClUnited Nations", Rome, 2002.

[39] S., Dong, and K ., Eog, "The removal by crab shell of mixed heavy metal ions in aqueous solution. Bio resource Technol.,87(3):353-357, 2003.

[40] S., Lu-shuguang, S., Gibb, and Cochrane, "Effective removal of zinc ions from aqueous solutions using crab carapace, bio sorbent". J. Hazar. Mater.149(1):208-217, 2007.

[41] W. J. , Langston, and S. K., Spence, ,"Biological factors 
involved in metal concentrations observed in aquatic organisms in, metal speciation and bioavailability in aquatic systems". Eds, Tessier, A. \& Turner, D.R. IUPAC, John
Wiley, 1995.

[42] Schram, F. R, "Stomatopoda, In , Crustacean". Oxford University Press. pp: 52-73,1986. 